\title{
Teaching and mindsets regarding sustainable development - a Mexican case study
}

\author{
David S. ZEPEDA QUINTANA, Javier ESQUER, Carlos ANAYA \\ University of Sonora, México
}

\begin{abstract}
:
Aim: The world has become increasingly interconnected and complex, posing serious challenges to sustainable development, which may be easily ignored as they are often of a low probability nature. This creates the need to identify and deal with these challenges. This research aims to identify if teaching interventions, applied to engineering students, produces changes in students' perceptions and mindset about business sustainability and sustainable development and, as consequence, support the creation of necessary cognitive capabilities for dealing with complex problems.
\end{abstract}

Design / Research methods: Questionnaires were applied in a Mexican university to students of a course in sustainable development. The experiment consists of three phases: (1) a pre-test ( $n=337),(2)$ intervention and (3) a post-test $(n=329)$ in order to assess the differences after the interventions.

Conclusions / findings: Changes in the students' perception were observed. While this on the one hand shows that teaching supports the creation of students' cognitive capabilities necessary to contribute to business sustainability, effects may also be contrary to what was intended. The results must be threated carefully; nevertheless, they provide the basis for further research.

Originality / value of the article: This paper provides a new perspective on the conditions for teaching sustainable development and sustainable business. It presents a case study on the development of students' awareness of and capacities to solve the complex problems of sustainable development

Keywords: Sustainable development, complexity, teaching interventions, education for sustainable development, functional stupidity

JEL: Q01, D81, A20

Contact details: David S. Zepeda, Javier Esquer, Carlos Anaya, University of Sonora, Hermosillo, México. E-mail: David S. Zepeda: david.zepeda@unison.mx, Javier Esquer javier.esquer@unison.mx, Carlos Anaya: canaya@industrial.uson.mx.

Received: 23.10.2019, Revised: 23.11.2019, Revised: 11.12.2019, Revised: 18.12.2019; Accepted: 18.12.2019.

doi: http://dx.doi.org/10.29015/cerem.860 


\section{Introduction}

Although sustainable business has become increasingly popular (at least the literature), there is no clear information or evidence available about successful practice (Dyllick, Muff 2016). On the contrary, it seems that problems have worsened due to the interconnectivity and complexity of human systems and activities (Helbing 2009; Taleb 2012). This situation may be the result of a lack of real understanding of the concept (Stubbs, Cocklin 2008; Bocken et al. 2014) or that we do not really have the proper information or capacity to solve these complex problems of business sustainability (Allen et al. 2014). In this context, the creation of human capital with the necessary capacities to generate sustainable strategies in an environment of complexity and uncertainty becomes relevant (Naveen 2006; Voss et al. 2007).

The world has become increasingly interconnected and complex (Taleb 2012). This represents a great challenge for sustainable business and consequently for sustainable development itself. When we talk about sustainable development, we usually talk about a balance between environment, society and economy; systems that face complex challenges individually and that require some knowledge, information and strategies in the task of finding solutions to complex problems (Miller et al. 2014). Therefore, a change is required not only in business management structures but also in the generation of talent and capabilities of professionals who make and will make decisions in business (Vora 2013).

During the last decades the application of knowledge management techniques has become widespread among firms and is currently set as a paradigm for management of business (Gonzalez, Martins 2017). However, this focus on knowledge may result in the neglect or ignorance of other equally important factors influencing the performance of businesses including the unknown (Carrillo 2007). Therefore, the development of instruments that reduces ignorance as well as fragilities of business are required, this with the intention of being prepared to deal with unexpected events that can threaten sustainability.

In this context, universities emerges as an interesting change factor since they have the responsibility to lead society towards a sustainable future through the 


\section{TEACHING AND MINDSETS REGARDING SUSTAINABLE DEVELOPMENT}

generation of professionals, managers and decision makers which play significant roles in national and global economies (Bekessy, Burgman, 2003). However, it seems that the talent and human resources that are being generated lack the capacity to face these complex problems (Lambrechts et al. 2013). To solve these complex problems, a set of skills is required that are not openly discussed or at least not explicitly in common teaching structures.

This research is based on the work of Platje et al. (2019). The authors refer to a "fragilizing mindset" among students that may poses challenges for sustainable development. This fragilizing mindset, according to the authors, is given by the following elements:

- Functional stupidity: According to the Alvesson and Spicer (2012), it refers to not voluntarily use intellectual abilities beyond the "here and now", that is, limiting cognitive and reflexive capacities to issues close to individuals in matters of time and distance (according to Platje et al (2019), in a myopic way). It consists of reflexivity, justification and substantive reasoning (Alvesson, Spicer 2012, based on Boltansky, Thévenot 2006; Alvesson, Skoldberg 2009).

- Adherence to techno-centric paradigm (mental models): This refers to the belief that technology can solve all the problems facing the world (Gladin et al. 1995). This can lead to the omission of events that can cause significant and irreversible damage that can lead to collapse scenarios (Platje 2016).

- Trust: The lack of trust in general can create difficulties in the search for cooperative solutions that require instant reactions in case of unexpected events. (Raiser et al. 2007).

- Lack of awareness of vulnerability and fragility issues: This refers to the need to be aware of fragilities in the systems (e.g. weakest links and bottlenecks) that can generate non-linear consequences. (Carrillo, 2007; Taleb 2007).

Based on this theoretical framework, an interesting question is whether universities, through the current teaching structures, can produce students with an non-fragilizing mindset that can reduce the challenges for sustainable development. 


\section{David S. ZEPEDA QUINTANA, Javier ESQUER, Carlos ANAYA}

This includes the generation of strategies that allows to reduce ignorance and the fragility of business. This paper presents a case study on the impact of teaching interventions on the perception and mindset of students regarding business sustainability and sustainable development with the intention to relate to the question whether universities are producing professionals with the necessary cognitive capabilities for the solution of complex problems that can lead us to collapse scenarios.

\section{Method}

In order to obtain relevant information about students' perception on business sustainability and the conditions for teaching development and sustainable business an experiment was carried out. The experiment consisted of the application of a questionnaire consisting of different statements that were evaluated with a 5-point Likert-items scale. The statements included in the questionnaire are directly related to the elements of a fragilizing mindset (Table 1).

Students had to assess the statements presented in Table 1 on a Likert-type scale in the range from (1) strongly disagree to (5) strongly agree, with the option "don't know". The questionnaires were carried out in 15 groups of students taking part in the subject "sustainability in the engineering" of the engineering division of the University of Sonora, México. The experiment consisted of three phases: (1) a pretest $(n=337),(2)$ intervention and (3) a post-test $(n=329)$ in order to assess the differences after the interventions. This experiment follows a similar procedure than the one presented in Platje et al. (2019).

\section{Procedure}

In Summer 2018, the questionnaires were filled out beginning of the semester. This in order to ensure that the opinion of the students was not compromised or subject to bias on the part of the teacher. The "Microsoft Forms" digital platform was used, which could accessed through a personal cell phone or laptop. 
Table 1. Items used for teaching experiment questionnaire

\begin{tabular}{|c|c|}
\hline Statement & $\begin{array}{l}\text { Elements of an anti- } \\
\text { fragile mindset }\end{array}$ \\
\hline $\begin{array}{l}\text { 1. The world increases in complexity so fast, that increase in knowledge } \\
\text { cannot keep up. }\end{array}$ & $\begin{array}{l}\text { Knowledge and } \\
\text { complexity }\end{array}$ \\
\hline 2. It is no problem when mistakes are not discussed in the company. & $\begin{array}{l}\text { Functional stupidity - } \\
\text { reflexivity }\end{array}$ \\
\hline $\begin{array}{l}\text { 3. It is no problem when it is impossible to doubt about and criticize } \\
\text { management decisions in a company. }\end{array}$ & $\begin{array}{l}\text { Functional stupidity - } \\
\text { substantive reasoning }\end{array}$ \\
\hline $\begin{array}{l}\text { 4. It is no problem when changes in the rules in a company are not openly } \\
\text { discussed. }\end{array}$ & $\begin{array}{l}\text { Functional stupidity - } \\
\text { reflexivity }\end{array}$ \\
\hline $\begin{array}{l}\text { 5. It is no problem when the management of a company does not provide } \\
\text { reasons and explanations for their decisions }\end{array}$ & $\begin{array}{l}\text { Functional stupidity - } \\
\text { justification }\end{array}$ \\
\hline $\begin{array}{l}\text { 6. It is no problem when a company ignores threats to its existence which are } \\
\text { difficult to quantify. }\end{array}$ & $\begin{array}{l}\text { Functional stupidity - } \\
\text { substantive reasoning }\end{array}$ \\
\hline 7. It is no problem when a company ignores low probability threats & $\begin{array}{l}\text { Functional stupidity - } \\
\text { substantive reasoning }\end{array}$ \\
\hline $\begin{array}{l}\text { 8. It is no problem for a company when it is dependent on one or a few main } \\
\text { suppliers. }\end{array}$ & Indicators of fragility \\
\hline $\begin{array}{l}\text { 9. It is no problem for a company when it is dependent on one or a few } \\
\text { customers. }\end{array}$ & Indicators of fragility \\
\hline $\begin{array}{l}\text { 10. It is no problem when people in the company do not provide feedback to } \\
\text { other people. }\end{array}$ & $\begin{array}{l}\text { Functional stupidity - } \\
\text { justification }\end{array}$ \\
\hline $\begin{array}{l}\text { 11. It is no problem when the innovations of a company make the } \\
\text { management more complex. }\end{array}$ & Indicators of fragility \\
\hline 12. In general, people can be trusted. & Trust \\
\hline $\begin{array}{l}\text { 13. The ecosystem is resilient - nature is able to deal with environmental } \\
\text { problems. }\end{array}$ & Mental models \\
\hline $\begin{array}{l}\text { 14. Technology will solve eventual problems with energy supply in the } \\
\text { future. }\end{array}$ & Mental models \\
\hline $\begin{array}{l}\text { 15. Innovations and development of technology will solve problems with } \\
\text { environmental pollution and overuse of natural resources. }\end{array}$ & Mental models \\
\hline 16. Traffic jams can be solved by building more roads. & Mental models \\
\hline 17. Climate change is not caused by human beings. & Mental models \\
\hline 18. We should sacrifice economic growth for preventing climate change. & Mental models \\
\hline 19. Climate change is a very dangerous threat to society. & Mental models \\
\hline 20. The social responsibility of business is to increase its profits. & Mental models \\
\hline $\begin{array}{l}\text { 21. It is no problem when innovations of a company increase the reliance on } \\
\text { high skilled, difficult to find employees. }\end{array}$ & Indicators of fragility \\
\hline $\begin{array}{l}\text { 22. A company should take unlikely disasters into consideration in crisis } \\
\text { management. }\end{array}$ & Indicators of fragility \\
\hline $\begin{array}{l}\text { 23. It is no problem when the innovations of a company make it reliant on } \\
\text { one or two suppliers. }\end{array}$ & Indicators of fragility \\
\hline 24. Stocks and buffers, which seem not to be useful, can be eliminated. & Indicators of fragility \\
\hline
\end{tabular}

Source: Platje et al. 2019, questions obtained from Joost Platje, WSB University in Wrocław, Poland.

The intervention phase of the experiment was an integral element of the course work, as the elements researched in the questionnaire fit into the course syllabus, 
which was dealt with in 12 workshops. During classes, theoretical and practical aspects of sustainable development were dealt with. Focus was on understanding the relationship between human activities and environmental deterioration, social and economic crises. Issues related to the aforementioned fragilizing mindset, nonlinearity (e.g. related to consumption habits and environmental deterioration), lowprobability events (e.g. business disasters such as Chernobyl and oil spills), lack of general trust (e.g. corruption in the political structures of Mexico) and adherence to technocentric paradigm (e.g. energy efficiency, industry 4.0) were topics discussed during class.

During the workshops, short lectures were given on topics such as complexity of systems, innovation, fragilities and "black swans". At the end ofg the course, the repeat questionnaire was carried out, using the same platform as for the first questionnaire. The participants were not informed the repeat questionnaire was the same as the first questionnaire. The duration of the workshops was $45-60$ minutes the time lapse between applications (phase 1 and phase 2) was approximately 4 months. SPSS was used for analysis. Analysis has been carried out based on statistical hypothesis testing in order to assess differences between the two samples.

\section{Results}

The answers to the items of the two groups are presented in Table 2. The groups were analyzed using a two-tailed test for hypothesis testing among groups and among pre and post test for each item. All items were tested for significant differences. In the table, means of pre-test and post-test are presented, as well as the differences, the z-statistic and the p-value for each item. A critical z-score value for rejection $\left(-z_{\alpha / 2}=-1.96\right.$ and $\left.z_{\alpha / 2}=1.96\right)$ was used assuming $5 \%$ significance level (split $2.5 \%$ each on either side) to test the following hypothesis:
(1) $\mathrm{H} 0 . \mu 1=\mu 2$
(2) H1. $\mu 1 \neq \mu 2$ 
Equation (1) establishes that the means of pre-test and post-test have no significant changes while equation (2) establishes that there exists a significative statistical change in the means.

After performing the statistical test for both samples, it was found that the null hypothesis cannot be rejected ( $\mathrm{z}=0.609 ; \mathrm{p}=0.2709)$, so it can be said that there are no significant statistical changes before and after the intervention; However, after performing the test for each of the questions, it was found that there are significant changes in items $1,2,3,4,6,7,8,14,16,18$ (Table 2).

The statement with the greatest variation between pre-test and post-test is statement 1 "The world increases in complexity so fast, that increase in knowledge cannot keep up". Most participants went from neither agree nor disagree to agree with this statement. This may be because issues related to the interconnection of systems, complexity and limitations of knowledge were explicitly discussed during the workshops.

Items 2-7 related to functional stupidity, show a decrease between pre-test and post-test. A tendency to agree less with statements such as "It is no problem when mistakes are not discussed in the company" and "It is no problem when a company ignores low probability threats" can be observed. This situation is interesting as it shows the reported willingness of the students to openly discuss situations that normally may be omitted.

Statement 8 "It is no problem for a company when it is dependent on one or a few main suppliers" showed a slight reduction in the level of agreement. It is worth mentioning that this situation may not only due to the intervention, but also to the economic context of the region where there is a strong dependence mainly on one or two industrial sectors (automotive and aerospace) which, during the realization period of the experiment, have suffered the impacts of the application of different policies and structural reforms by the federal government. 
Table 2. Results of two tailed test

\begin{tabular}{|l|l|l|l|l|l|}
\hline \multicolumn{1}{|c|}{ Statement } & $\begin{array}{c}\text { Pre- } \\
\text { test } \\
\text { mean }\end{array}$ & $\begin{array}{c}\text { Post- } \\
\text { test } \\
\text { mean }\end{array}$ & Differences* & z-statistic & p-value \\
\hline $\begin{array}{l}\text { 1. The world increases in } \\
\text { complexity so fast, that increase in } \\
\text { knowledge cannot keep up. }\end{array}$ & 3.018 & 3.605 & 0.587 & -6.33 & $0.000^{* * *}$ \\
\hline $\begin{array}{l}\text { 2. It is no problem when mistakes } \\
\text { are not discussed in the company. }\end{array}$ & 1.843 & 1.529 & -0.314 & 4.15 & $0.000^{* * *}$ \\
\hline $\begin{array}{l}\text { 3. It is no problem when it is } \\
\text { impossible to doubt about and } \\
\text { criticize management decisions in } \\
\text { a company. }\end{array}$ & 2.003 & 1.763 & -0.240 & 3.06 & $0.000^{* * *}$ \\
\hline $\begin{array}{l}\text { 4. It is no problem when changes } \\
\text { in the rules in a company are not } \\
\text { openly discussed. }\end{array}$ & 1.935 & 1.760 & -0.175 & 2.35 & $0.009 * * *$ \\
\hline $\begin{array}{l}\text { 5. It is no problem when the } \\
\text { management of a company does } \\
\text { not provide reasons and } \\
\text { explanations for their decisions }\end{array}$ & 1.769 & 1.766 & -0.003 & 0.04 & 0.484 \\
\hline $\begin{array}{l}\text { 6. It is no problem when a } \\
\text { company ignores threats to its } \\
\text { existence which are difficult to } \\
\text { quantify. }\end{array}$ & 1.763 & 1.608 & -0.155 & 2.36 & $0.009 * * *$ \\
\hline $\begin{array}{l}\text { 7. It is no problem when a } \\
\text { company ignores low probability } \\
\text { threats }\end{array}$ & 2.145 & 1.888 & -0.258 & 3.64 & $0.000^{* * *}$ \\
\hline $\begin{array}{l}\text { 8. It is no problem for a company } \\
\text { when it is dependent on one or a } \\
\text { few main suppliers. }\end{array}$ & 2.457 & 2.207 & -0.250 & 3.07 & $0.000^{* * *}$ \\
\hline $\begin{array}{l}\text { 9. It is no problem for a company } \\
\text { when it is dependent on one or a } \\
\text { few customers. }\end{array}$ & 2.148 & 2.006 & -0.142 & 1.84 & 0.033 \\
\hline $\begin{array}{l}\text { 10. It is no problem when people } \\
\text { in the company do not provide } \\
\text { feedback to other people. }\end{array}$ & 1.970 & 1.991 & 0.021 & -0.29 & 0.386 \\
\hline $\begin{array}{l}\text { 11. It is no problem when the } \\
\text { innovations of a company make } \\
\text { the management more complex. }\end{array}$ & 2.766 & 2.784 & 0.019 & -0.19 & 0.425 \\
\hline $\begin{array}{l}\text { 12. In general, people can be } \\
\text { trusted. }\end{array}$ & 2.970 & 2.845 & -0.125 & 1.40 & 0.081 \\
\hline
\end{tabular}


Table 2. Cont. ...

\begin{tabular}{|l|l|l|l|l|l|}
\hline Statement & $\begin{array}{l}\text { Pre- } \\
\text { test } \\
\text { mean }\end{array}$ & $\begin{array}{l}\text { Post- } \\
\text { test } \\
\text { mean }\end{array}$ & Differences* & z-statistic & p-value \\
\hline $\begin{array}{l}\text { 13. The ecosystem is resilient - } \\
\text { nature is able to deal with } \\
\text { environmental problems. }\end{array}$ & 2.080 & 2.061 & -0.019 & 0.23 & 0.409 \\
\hline $\begin{array}{l}\text { 14. Technology will solve eventual } \\
\text { problems with energy supply in the } \\
\text { future. }\end{array}$ & 2.958 & 2.608 & -0.351 & 3.33 & $0.000 * * *$ \\
\hline $\begin{array}{l}\text { 15. Innovations and development of } \\
\text { technology will solve problems with } \\
\text { environmental pollution and overuse } \\
\text { of natural resources. }\end{array}$ & 2.629 & 2.459 & -0.170 & 1.75 & 0.040 \\
\hline $\begin{array}{l}\text { 16. Traffic jams can be solved by } \\
\text { building more roads. }\end{array}$ & 2.774 & 2.505 & -0.270 & 2.97 & $0.001 * * *$ \\
\hline $\begin{array}{l}\text { 17. Climate change is not caused by } \\
\text { human beings. }\end{array}$ & 1.688 & 1.693 & 0.005 & -0.06 & 0.476 \\
\hline $\begin{array}{l}\text { 18. We should sacrifice economic } \\
\text { growth for preventing climate } \\
\text { change. }\end{array}$ & 3.279 & 2.982 & -0.297 & 3.19 & $0.000 * * *$ \\
\hline $\begin{array}{l}\text { 19. Climate change is a very } \\
\text { dangerous threat to society. }\end{array}$ & 4.306 & 4.301 & -0.005 & 0.06 & 0.476 \\
\hline $\begin{array}{l}\text { 20. The social responsibility of } \\
\text { business is to increase its profits. }\end{array}$ & 2.641 & 2.696 & 0.055 & -0.55 & 0.291 \\
\hline $\begin{array}{l}\text { 21. It is no problem when } \\
\text { innovations of a company increase } \\
\text { the reliance on high skilled, difficult } \\
\text { to find employees. }\end{array}$ & 2.730 & 2.626 & -0.104 & 1.05 & 0.147 \\
\hline $\begin{array}{l}\text { 22. A company should take unlikely } \\
\text { disasters into consideration in crisis } \\
\text { management. }\end{array}$ & 3.822 & 4.009 & 0.187 & -2.27 & 0.012 \\
\hline $\begin{array}{l}\text { 23. It is no problem when the } \\
\text { innovations of a company make it } \\
\text { reliant on one or two suppliers. }\end{array}$ & 2.454 & 2.337 & -0.117 & 1.39 & 0.082 \\
\hline $\begin{array}{l}\text { 24. Stocks and buffers, which seem } \\
\text { not to be useful, can be eliminated. }\end{array}$ & 2.890 & 2.675 & -0.215 & 2.12 & 0.017 \\
\hline $\begin{array}{l}\text { A positive number implies that the level of agreement with the statement increased. A negative } \\
\text { number implies that the level of agreement with the statement decreased. Note. *** p }\end{array}$ \\
\hline
\end{tabular}

Items 14,16 and 18 are related to adherence to the technocentric paradigm. During the class, issues involving the confidence of markets, companies and society in general in which technology will help us find solutions to complex problems related to sustainability and directly related to the development and survival of the 
species were discussed. However, statement 18 "We should sacrifice economic growth for preventing climate change" underwent an interesting modification. Students reduced their level of agreement with this item when reverse behavior could be expected. This may be due to the fact that during the classes, the balance that is intended to be found between the economic, environmental and social perspective in all strategies and policies for sustainable development is emphasized.

Finally, statements 22 and 24 related to the indicators of fragility show an interesting behavior. The statement "A company should take unlikely disasters into consideration in crisis management" (22) showed an increase in the level of agreement after the intervention while the statement "Stocks and buffers, which seem not to be useful, can be eliminated" (24) presented a reduction in the level of agreement. This may be because during classes and workshops the importance of the systems approach in solving complex problems as well as in low probability events and non-linear effects were emphasized.

\section{Discussion and conclusion}

First of all, these results should be carefully analyzed since they do not represent the perception of all students. The study was carried out in the engineering faculty of the university which has a specific academic and cultural direction. However, it is interesting to observe the modifications found in the perception of the students.

The results obtained show changes in the students' perception in some of the statements related to functional stupidity, lack of general trust, indicators of fragility and mental models. This means that the conditions for teaching sustainable development and sustainable business in this case of study can potentially contribute to creating in students the cognitive capabilities necessary to generate an nonfragilizing mindset and, consequently, contribute to business sustainability and sustainable development.

The research shown here only represents the case of one university with a very specific academic and cultural context; It is necessary to repeat this experiment in 


\section{TEACHING AND MINDSETS REGARDING SUSTAINABLE DEVELOPMENT}

\section{different faculties and universities in order to identify if students of different disciplines suffer the same modifications in their perceptions.}

\section{References}

Ahern, J. (2011), From fail-safe to safe-to-fail: Sustainability and resilience in the new urban world, "Landscape and urban Planning", vol. 100 no.4, pp.341-343.

Allen, J.H., Beaudoin, F., Lloyd-Pool, E., Sherman, J., (2014), Pathways to sustainability careers: building capacity to solve complex problems, "Sustainability: The Journal of Record", vol. 7 no.1, pp.47-53.

Alvesson, M., Skoldberg, K. (2009), positivism, social constructionism, critical realism: Three reference points in the philosophy of science, "Reflexive methodology: New vistas for qualitative research", pp.15-52.

Alvesson, M., Spicer, A. (eds., (2010). Metaphors we lead by: Understanding leadership in the real world, Routledge, Abingdon.

Bekessy, S., Burgman, M. (2003), Universities and sustainability, "TELA: Environment, Economy and Society", no.11, pp.1-4.

Bocken, N.M., Short, S.W., Rana, P., Evans, S. (2014), A literature and practice review to develop sustainable business model archetypes, "Journal of Cleaner Production", vol. 65, pp.42-56.

Boltanski, L., Thévenot, L., (2006), On justification: Economies of worth, Princeton University Press, Princeton.

Carrillo, F.J. (2007), The coming of age of knowledge-based development, "Journal of Knowledge Management", vol.11 no.5, pp.3-5.

Dwivedi, M. (2010), Role of media in disaster management and early warning, Amity Institute of Disaster Management.

Dyllick, T., Muff, K. (2016), Clarifying the meaning of sustainable business: Introducing a typology from business-as-usual to true business sustainability, "Organization \& Environment", vol. 29 no.2, pp.156-174.

Gladwin, T.N., Kennelly, J.J., Krause, T.S. (1995), Shifting paradigms for sustainable development: Implications for management theory and research, "Academy of management Review", vol.20 no.4, pp. 874-907.

Gonzalez, R.V.D., Martins, M.F. (2017), Knowledge management process: a theoretical-conceptual research, "Gestão \& Produção", vol.24 no.2, pp.248-265.

Helbing, D. (2009), Managing complexity in socio-economic systems, "European Review", vol.17 no.2, pp. 423-438.

Vora, K.M., (2013), Business excellence through sustainable change management, "The TQM Journal", vol.25 no.6, pp.625-640. 


\section{David S. ZEPEDA QUINTANA, Javier ESQUER, Carlos ANAYA}

Lambrechts, W., Mulà, I., Ceulemans, K., Molderez, I., Gaeremynck, V. (2013), The integration of competences for sustainable development in higher education: an analysis of bachelor programs in management, "Journal of Cleaner Production", vol. 48, pp. 65-73.

Mandelbrot, B.B., Hudson, R.L. (2010), The (mis) behaviour of markets: a fractal view of risk, ruin and reward, Profile Books, London.

Miller, T.R., Wiek, A., Sarewitz, D., Robinson, J., Olsson, L., Kriebel, D., Loorbach, D. (2014), The future of sustainability science: a solutions-oriented research agenda, "Sustainability science", vol.9 no.2, pp.239-246.

Murphy, K., Packer, C., Stevens, A., Simpson, S. (2007), Effective early warning systems for new and emerging health technologies: Developing an evaluation framework and an assessment of current systems, "International journal of technology assessment in health care", vol.23 no.3, pp.324-330.

Naveen, L. (2006), Organizational complexity and succession planning, "Journal of Financial and Quantitative Analysis", vol.41 no.3, pp.661-683.

Platje, J. (2016), Efficiency, fragility and unsustainable development, "Prace Naukowe Uniwersytetu Ekonomicznego we Wrocławiu", vol.452, pp.46-57.

Platje, J.., Will, M., Van Dam, Y.K., (2019), A fragility approach to sustainability-researching effects of education. “Journal of Sustainability in Higher Education”, vol. 20 no. 7, pp. 1220-1239.

Raiser, M., Rousso, A., Steves, F., Teksoz, U. (2007), Trust in transition: Cross-country and firm evidence. "The Journal of Law, Economics, \& Organization", vol.24 no.2, pp.407-433.

Rouse, M. (2016), What is early warning system?, https://whatis.techtarget.com/definition/earlywarning-system [20.10.2019].

Stubbs, W., Cocklin, C., (2008), Conceptualizing a "sustainability business model", "Organization \& environment”, vol. 21 no.2, pp.103-127.

Taleb, N.N., (2007), The black swan: The impact of the highly improbable, Random house, New York.

Taleb, N. N. (2012), Antifragile: how to live in a world we don't understand, Allen Lane, London.

Taleb, N.N., Martin, G.A., (2012), How to prevent other financial crises, "SAIS Review of International Affairs", vol.32 no.1, pp.49-60.

Voss, J.P., Newig, J., Kastens, B., Monstadt, J., Nölting, B., (2007), Steering for sustainable development: a typology of problems and strategies with respect to ambivalence, uncertainty and distributed power, "Journal of Environmental Policy \& Planning", vol.9 no.3-4, pp.193-212. 